\title{
CORRELATION OF TOTAL LEUCOCYTE COUNT, EOSINOPHIL, NEUTROPHIL AND LYMPHOCYTE COUNTS WITH PULMONARY FUNCTION IN COPD PATIENTS
}

\author{
Sureshbalaji R. A1, Prem Kumar $S^{2}$, Lavanya $R^{3}$, Krishna Kumar $S^{4}$, Sivapriya D.V5, Ramaswamy $C^{6}$, Shyamala Thirumeni ${ }^{7}$ \\ ${ }^{1}$ Tutor, Department of Physiology, Chennai Medical College Hospital and Research Centre, Irungalur, Tiruchirapalli. Tamilnadu. \\ ${ }^{2}$ Assistant Professor, Saveetha Medical College Hospital and Research Centre, Thandalam, Chennai, Tamilnadu. \\ ${ }^{3}$ Homoeo Consultant, SKY Jyothi Homoeo Clinic, Temple of Consciousness, Aliyar, Pollachi, Tamilnadu. \\ ${ }^{4}$ Assistant Professor, Department of Physiology, Chennai Medical College Hospital and Research Centre, Irungalur, Tiruchirapalli. \\ ${ }_{5}^{5}$ Associate Professor, Saveetha Medical College Hospital and Research Centre, Chennai, Tamilnadu. \\ ${ }^{6}$ Professor, Department of Physiology, Saveetha Medical College and Hospital, Thandalam, Chennai, Tamilnadu. \\ ${ }^{7}$ Professor, Department of Physiology, Saveetha Medical College and Hospital, Thandalam, Chennai, Tamilnadu.
}

\section{BACKGROUND}

ABSTRACT

Chronic obstructive pulmonary disease (COPD) is the fourth leading cause of death in India. In COPD, there is an increased number of leucocytes, suggesting a role for the inflammatory response in the clinical progression of the disease.

The aim of the study is to evaluate the degree of pulmonary function impairment by pulmonary function tests and to correlate leucocyte counts with pulmonary function tests in COPD patients.

\section{MATERIALS AND METHODS}

This descriptive study was carried out among 30 COPD volunteers (patients) referred from Pulmonology Department of Saveetha Hospital. The pulmonary function test was done by using a computerised spirometer and complete blood cell count was also made for all the subjects. Pulmonary parameters ( $\mathrm{FEV}_{1}$ and PEFR) recorded were correlated with blood parameters (TLC, neutrophils, eosinophils, lymphocytes).

\section{RESULTS}

There was strong negative significant correlation observed between $\mathrm{FEV}_{1}$ and TLC, absolute neutrophil count, absolute eosinophil count whereas there exists a weak negative significant correlation between $\mathrm{FEV}_{1}$ and absolute lymphocyte count $(\mathrm{p}<0.05)$.

\section{CONCLUSION}

The findings indicated that whenever the blood parameters (TLC, neutrophils, eosinophils and lymphocytes) increase there was a decrease in the pulmonary parameters in COPD patients.

\section{KEYWORDS}

COPD, Computerised Spirometer, FEV 1 .

HOW TO CITE THIS ARTICLE: Sureshbalaji RA, Kumar PS, Lavanya R, et al. Correlation of total leucocyte count, eosinophil, neutrophil and lymphocyte counts with pulmonary function in COPD patients. J. Evolution Med. Dent. Sci. 2017;6(83):00-00, DOI: 1. J. Evolution Med. Dent. Sci. 2017;6(84):5870-5873, DOI: 10.14260/jemds/2017/1275

\section{BACKGROUND}

Chronic obstructive pulmonary disease (COPD) is the fourth leading cause of death in India and a major worldwide healthcare problem. ${ }^{1}$ Chronic obstructive pulmonary disease (COPD) is characterised by the progressive, partially reversible air flow limitation which occurs in association with a chronic inflammatory reaction triggered by smoking or other inhalation in predisposed subjects. ${ }^{1}$

Leucocytes are important cells which mediate various inflammatory responses. Inflammation has been identified as an important factor for disease exacerbation in obstructive lung disease. In this study, we used neutrophil and eosinophil counts as biomarkers for exacerbation in obstructive lung disease. ${ }^{2}$

'Financial or Other Competing Interest': None.

Submission 14-09-2017, Peer Review 07-10-2017,

Acceptance 14-10-2017, Published 19-10-2017.

Corresponding Author:

Dr. Prem Kumar $S$,

Assistant Professor

Saveetha Medical College Hospital and Research Centre,

Thandalam, Chennai, Tamilnadu

E-mail: bptkidbalaji@gmail.com

DOI: $10.14260 /$ jemds/2017/1275
It has been suggested that with severe COPD, there is an increased number of leucocytes, which is correlated with PFT suggesting a role for this inflammatory response in the clinical progression of the disease. ${ }^{3}$

Pulmonary Function Tests (PFTs) are very important in the medical evaluation of patients suffering from "shortness of breath", and they are effectively used for the diagnosis of pulmonary diseases, such as COPD (i.e. chronic obstructive pulmonary diseases). Measurement of Forced Vital Capacity (FVC) and Forced Expiratory Flow in the $1^{\text {st }}$ second $\left(\mathrm{FEV}_{1}\right)$ are very important for assessing the treatment of COPD. ${ }^{4}$

A number of studies have demonstrated the association between the reversibility of obstructive pulmonary function impairments and the number of leucocytes in peripheral blood. There is paucity of literature concerned with the relationship between markers of allergy, and airway inflammation and pulmonary function results in COPD. 5 So this study has been designed to correlate total leucocyte count, eosinophil (anti-allergy), neutrophil (antiinflammatory) and lymphocyte counts with pulmonary function in COPD patients.

\section{MATERIALS AND METHODS \\ Study Design \\ Descriptive study.}




\section{Methodology}

The present analytical study was carried out among 30 COPD volunteers (patients) referred from Pulmonology Department of Saveetha Hospital.

\section{Inclusion Criteria}

- Patients with COPD only.

- Age between 20-60 years.

- Both gender.

- Chronic bronchitis.

- Emphysema.

- Bronchiectasis.

- Bronchial asthma (with attack \& follow-up).

\section{Exclusion Criteria}

Subjects with the following diseases were excluded

- Epilepsy.

- Infective diseases.

- Cardiac diseases.

- Mentally retarded subjects.

\section{Procurement of Permissions}

The protocol and the benefits of the study were explained to the subjects and written consent was also obtained from subjects before carrying out the study on the subjects.

\section{Ethical Clearance}

The study proposal with the informed consent and the questionnaire were submitted to the ethical committee of our institution and was approved by the ethical committee.

\section{Pulmonary Function Test}

Instrument used for measuring

$\mathrm{FEV}_{1}$ - Computerised Spirometer, (RMS Helios 401, Recorders and Medicare Systems (P) Ltd).

\section{Blood Analysis}

- Total leucocyte count was done by manual method using haemocytometer.

- Differential leucocyte count was done by standard procedure of eosin and haematoxylin staining method.

\section{Procedure \\ PFT Recording}

- During recording, the patient was made to sit in high sitting position and asked to relax for $5 \mathrm{~min}$.

- Soft nose clips were used to prevent air escaping through the nose.

- Sterile filter mouthpieces were used to prevent the spread of microorganisms
- The test was preceded by a period of quiet breathing in and out into the sensor through the mouth (tidal volume), or the rapid breath in (forced inspiratory part), which would come before the forced exhalation.

- The patient was asked to take a deep breath as forcefully as they can, and then exhale into the sensor as hard as possible preferably at least for 6 seconds.

- The manoeuvre is highly dependent on patient cooperation and effort.

- After the patients were educated about the procedure, the tests were carried out three times and best of the three was selected for analysis.

- The values obtained by the sensor were recorded.

\section{Pulmonary Parameters}

PEFR \& $\mathrm{FEV}_{1}$ values taken from computerised spirometric chart.

\section{Blood Parameters}

1. Total Leucocyte Count

- Using WBC pipette, Turk's fluid and Neubauer's counting chamber.

- TLC $\left(\right.$ cells $\left./ \mathrm{mm}^{3}\right)=$ cells counted $\times 50$.

2. Differential Leucocyte Count

- Chart containing 100 counters were made.

- Type of leucocytes was registered in each counter.

- DLC was made by adding the registered counts.

- Percentage of DLC was made.

- Absolute Count was made as follows

i. Absolute neutrophil count $=$ neutrophil $\% \times$ TLC.

ii. Absolute eosinophil count $=$ eosinophil $\% \times$ TLC.

iii. Absolute lymphocyte count $=$ lymphocyte $\% \times$ TLC.

\section{Statistical Analysis}

Data obtained were represented as Mean \pm SD. Correlation coefficient was calculated between lung function test variables $\left(\mathrm{FEV}_{1}\right)$ and blood examination results (Neutrophils, eosinophils \& lymphocytes).

\section{RESULTS}

In this study, 30 patients who were diagnosed as COPD from the Pulmonology Department of Saveetha Hospital participated voluntarily. Pulmonary parameters $\left(\mathrm{FEV}_{1}\right.$ and PEFR) recorded were correlated with blood parameters (TLC, neutrophils, eosinophils, lymphocytes) and compared with "p-value".

The results are given below.

\begin{tabular}{|c|c|c|c|c|c|}
\hline \multirow{2}{*}{$\begin{array}{c}\text { No. of } \\
\text { Subjects }\end{array}$} & $\begin{array}{c}\text { FEV }_{1} \\
(\%) \\
\end{array}$ & \multirow{2}{*}{\multicolumn{2}{|c|}{ 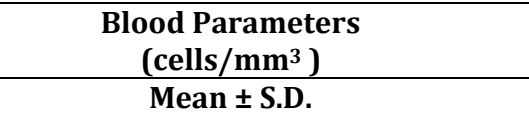 }} & \multirow{2}{*}{$\begin{array}{c}\text { Correlation } \\
\text { Coefficient }\end{array}$} & \multirow{2}{*}{$\begin{array}{c}\text { 'p' } \\
\text { value }\end{array}$} \\
\hline & Mean \pm S.D. & & & & \\
\hline \multirow{4}{*}{30} & \multirow{4}{*}{$38.5 \pm 17.6$} & TLC & $12,800 \pm 1301.9$ & -0.80 & \multirow{4}{*}{$\mathrm{p}<0.05$} \\
\hline & & ABS.NEU.CNT & $7369.2 \pm 952.01$ & -71 & \\
\hline & & ABS.EOS.CNT & $811.03 \pm 228.72$ & -73 & \\
\hline & & ABS.LYM.CNT & $3848 \pm 516.03$ & -30 & \\
\hline
\end{tabular}




\begin{tabular}{|c|c|c|c|c|c|}
\hline \multirow{2}{*}{$\begin{array}{c}\text { No. of } \\
\text { Subjects }\end{array}$} & $\begin{array}{c}\text { PEFR } \\
\text { (L/min.) } \\
\end{array}$ & \multicolumn{2}{|c|}{$\begin{array}{c}\text { Blood Parameters } \\
\text { (cells } / \mathrm{mm}^{3} \text { ) }\end{array}$} & \multirow{2}{*}{$\begin{array}{l}\text { Correlation } \\
\text { Coefficient }\end{array}$} & \multirow{2}{*}{$\begin{array}{c}\text { 'p' } \\
\text { value }\end{array}$} \\
\hline & Mean \pm S.D. & & S.D. & & \\
\hline \multirow{4}{*}{30} & \multirow{4}{*}{$215 \pm 49.39$} & TLC & $12,800 \pm 1301.9$ & -0.80 & \multirow{4}{*}{$\mathrm{p}<0.05$} \\
\hline & & ABS.NEU.CNT & $7369.2 \pm 952.01$ & -73 & \\
\hline & & ABS.EOS.CNT & $811.03 \pm 228.72$ & -60 & \\
\hline & & ABS.LYM.CNT & $3848 \pm 516.03$ & -38 & \\
\hline \multicolumn{6}{|c|}{ Table 2. Correlation between PEFR and Blood Parameters } \\
\hline
\end{tabular}

\begin{tabular}{|c|c|c|c|c|}
\hline $\begin{array}{c}\text { No. of } \\
\text { Subjects }\end{array}$ & $\begin{array}{c}\text { FEV } 1 \\
(\%)\end{array}$ & $\begin{array}{c}\text { TLC } \\
\left(\text { Cells } / \mathbf{m m}^{3} \text { ) }\right.\end{array}$ & $\begin{array}{c}\text { Correlation } \\
\text { Coefficient }\end{array}$ & $\begin{array}{c}\text { 'p' } \\
\text { value }\end{array}$ \\
\cline { 2 - 4 } Mean \pm S.D. & Mean \pm S.D. & & \\
\hline 30 & $38.5 \pm 17.6$ & $12,800 \pm 1301.9$ & -0.80 & $\mathrm{p}<0.05$ \\
\hline \multicolumn{5}{|c|}{ Table 3. Correlation between FEV 1 and Total Leucocyte } \\
Count (TLC)
\end{tabular}

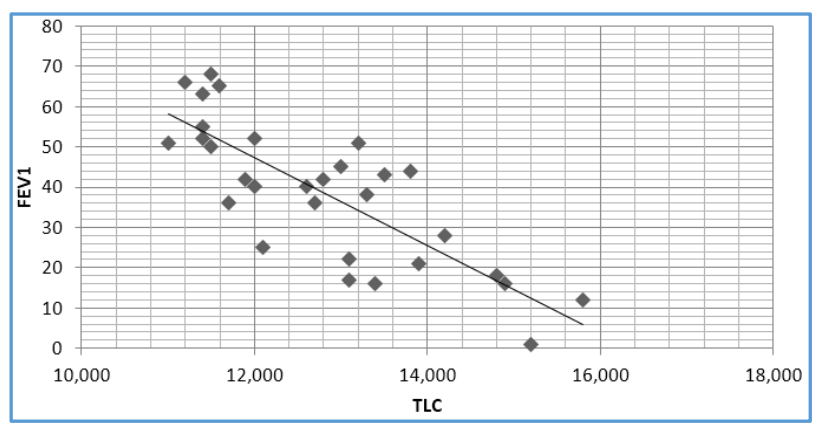

Figure 1

The mean value of $\mathrm{FEV}_{1}$ was $38.5 \pm 17.6$ and mean TLC value was $12,800 \pm 1301.9$. (Table: 3 ). When these two values were compared, the result showed that there was a strong negative significant correlation $(-0.80)$ noted between $\mathrm{FEV}_{1}$ and TLC $(\mathrm{p}<0.05)$.

\begin{tabular}{|c|c|c|c|c|}
\hline $\begin{array}{c}\text { No. of } \\
\text { Subjects }\end{array}$ & $\begin{array}{c}\text { FEV } 1 \\
\text { (\%) }\end{array}$ & $\begin{array}{c}\text { ABS.NEU.CNT } \\
\text { (cells/mm }{ }^{3} \text { ) }\end{array}$ & $\begin{array}{c}\text { Correlation } \\
\text { coefficient }\end{array}$ & $\begin{array}{c}\text { 'p' } \\
\text { value }\end{array}$ \\
\cline { 2 - 4 } & Mean \pm S.D. & Mean \pm S.D. & & p < 0.05 \\
\hline 30 & $38.5 \pm 17.6$ & $\begin{array}{c}7369.2 \pm \\
952.01\end{array}$ & -0.71 & \\
\hline \multicolumn{5}{|c|}{ Table 4. Correlation between FEV 1 and Absolute Neutrophil } \\
Count
\end{tabular}

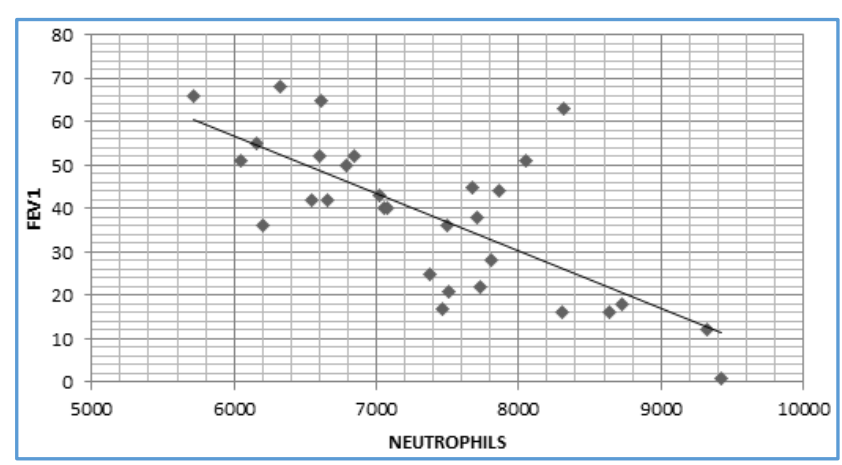

Figure 2

The mean $\mathrm{FEV}_{1}$ value was $38.5 \pm 17.6$ and mean absolute neutrophil count value was $7369.2 \pm 952.01$. (Table: 4 ). On comparing these two values, the result showed that there exists a strong negative significant correlation (-0.71) between $\mathrm{FEV}_{1}$ and absolute neutrophil count $(\mathrm{p}<0.05)$.

\begin{tabular}{|c|c|c|c|c|}
\hline $\begin{array}{c}\text { No. of } \\
\text { Subjects }\end{array}$ & $\begin{array}{c}\text { FEV } 1 \\
\text { (\%) }\end{array}$ & $\begin{array}{c}\text { ABS.EOS.CNT } \\
\text { (cells/mm } / \mathbf{m m}^{3} \text { ) }\end{array}$ & $\begin{array}{c}\text { Correlation } \\
\text { coefficient }\end{array}$ & $\begin{array}{c}\text { 'p' } \\
\text { value }\end{array}$ \\
\cline { 2 - 4 } Mean \pm S.D. & Mean \pm S.D. & & \\
\hline 30 & $38.5 \pm 17.6$ & $811.03 \pm 228.72$ & -0.73 & $\mathrm{p}<0.05$ \\
\hline
\end{tabular}

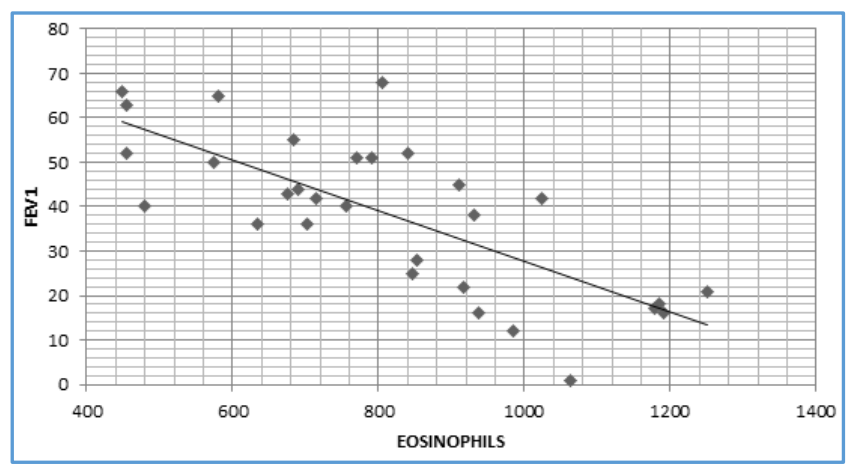

Figure 3

The mean value of $\mathrm{FEV}_{1}$ was $38.5 \pm 17.6$ and mean absolute eosinophil count value was $811.03 \pm 228.72$. (Table: 5) On comparing these two values, the result showed that there was a strong negative significant correlation $(-0.73)$ noted between $\mathrm{FEV}_{1}$ and absolute eosinophil count $(\mathrm{p}<0.05)$.

\begin{tabular}{|c|c|c|c|c|}
\hline \multirow{2}{*}{$\begin{array}{l}\text { No. of } \\
\text { Subjects }\end{array}$} & $\begin{array}{c}\text { FEV } 1 \\
(\mathrm{~L} / \mathrm{min} .)\end{array}$ & $\begin{array}{l}\text { ABS.LYM.CNT } \\
\left.\text { (cells } / \mathbf{m m}^{3}\right)\end{array}$ & \multirow[t]{2}{*}{$\begin{array}{l}\text { Correlation } \\
\text { coefficient }\end{array}$} & \multirow{2}{*}{$\begin{array}{c}\text { 'p' } \\
\text { Value }\end{array}$} \\
\hline & Mean \pm S.D. & Mean \pm S.D. & & \\
\hline 30 & $38.5 \pm 17.6$ & $3848 \pm 516.03$ & -0.30 & $\mathrm{p}<0.05$ \\
\hline \multicolumn{5}{|c|}{$\begin{array}{c}\text { Table 6. Correlation Between FEV } V_{1} \text { and Absolute } \\
\text { Lymphocyte Count }\end{array}$} \\
\hline
\end{tabular}

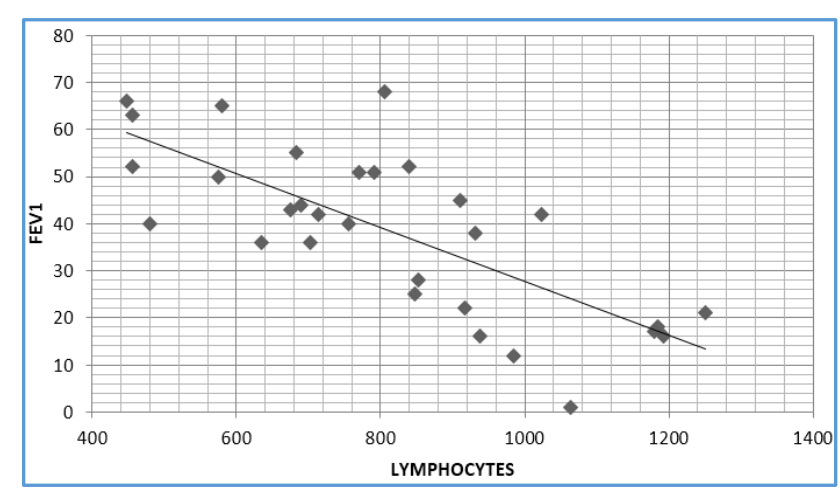

Figure 4

The mean value of $\mathrm{FEV}_{1}$ was $38.5 \pm 17.6$ and mean absolute lymphocyte count value was $3848 \pm 516.03$ (Table $6)$. These two values were compared. The result showed that there was weak negative significant correlation $(-0.30)$ observed between $\mathrm{FEV}_{1}$ and absolute lymphocyte count $(\mathrm{p}<0.05)$. 


\section{DISCUSSION}

COPD, the disease which affects the respiratory system, is normally diagnosed by certain pulmonary function tests. Among that measurement, Forced Vital Capacity (FVC), Forced Expiratory Flow in the $1^{\text {st }}$ second $\left(\mathrm{FEV}_{1}\right)$ are very important for assessing the treatment of COPD. FEV 1 determines the severity of air flow obstruction.

It has been suggested that with severe COPD, there is an increase in number of leucocytes, which is correlated with PFT suggesting a role for leucocytes in this inflammatory response in the clinical progression of the disease. ${ }^{3}$

Leucocytes are important haemocytic cells which mediate various inflammatory responses. Inflammation has been identified as an important factor for disease exacerbation in obstructive lung disease. ${ }^{6}$

A significant increase in TLC with decrease in $\mathrm{FEV}_{1}$ is noticed in the study. Decrease in $\mathrm{FEV}_{1}$ indicates the severity of COPD. As the leucocytes have the important role in body's defence mechanism, it is natural that their numbers increase with the severity of COPD. The present result also supports the abovementioned fact.

Further, to find out the relative role of individual leucocytes, the PFTs were compared with different leucocytes. There was a significant increase in absolute neutrophil count observed with decrease in $\mathrm{FEV}_{1}$ and PEFR. Neutrophils have been implicated in the pathogenesis of COPD, being recruited into the lung in response to cigarette smoke inhalation and being responsible for the release of protease and oxidant-producing enzymes that cause bronchitis and emphysema. ${ }^{7}$

An increase in the white blood cells that may be produced during an allergic reaction (eosinophils) may indicate that a condition such as asthma is causing the symptoms. In our results also, there was significantly high increase in absolute eosinophil count with decrease in $\mathrm{FEV}_{1}$.

On the contrary, the results of the lymphocytes showed a different correlation with PFTs. When the absolute lymphocyte count registered an increase, the PEFR showed a decrease and the $\mathrm{FEV}_{1}$ showed an increase. Lymphocytes are important effector and regulatory cells that participate actively in the inflammatory response of COPD especially for subjects who develop COPD from smoking. ${ }^{8}$ The inflammatory response of lymphocyte in COPD patients may be the cause for reduction in PEFR.

Thus, our study concludes that both pulmonary and blood parameters are showing a negative correlation. This inverse relationship if established may help the family physician to understand the severity of COPD and direct them to the referral centre for early diagnosis and treatment.

In short, the findings of this study indicate that the severity of COPD diagnosed with pulmonary function tests have negative correlation with the blood parameters i.e., whenever the blood parameters (TLC, neutrophils, eosinophils and lymphocytes) increase there was a decrease in the pulmonary test parameters in COPD patients.

\section{CONCLUSION}

- There was a strong negative significant correlation observed between FEV 1 and TLC, absolute neutrophil count, absolute eosinophil count whereas there exists a weak negative significant correlation between $\mathrm{FEV}_{1}$ and absolute lymphocyte count.

- Further studies on these lines are required to prove this inverse relationship of blood parameters and pulmonary parameters.

\section{REFERENCES}

[1] Fira-Mladinescu 0 , Tudorache V, Mihăicută S, et al. New concepts in the pathogenesis and pathophysiology of COPD. Pneumologia (Bucharest, Romania). 2006;56(1):24-6.

[2] Velthove KJ, Bracke M, Souverein PC, et al. Identification of exacerbations in obstructive lung disease through biomarkers. Biomarkers 2009;14(7):523-8.

[3] Turato G, Zuin R, Miniati M, et al. Airway inflammation in severe chronic obstructive pulmonary disease: relationship with lung function and radiologic emphysema. American Journal of Respiratory and Critical Care Medicine 2002;166(1):105-10.

[4] Üncü Ü. Evaluation of pulmonary function tests by using fuzzy logic theory. Journal of Medical Systems 2010;34(3):241-50.

[5] Chattopadhyay BP, Mahata A, Kundu S, et al. A study on blood eosinophil level and ventilatory pulmonary function of the workers exposed to storage grain dust. Indian Journal of Occupational and Environmental Medicine 2007;11(1):21-5.

[6] Annesi I, Kauffmann F, Oryszczyn MP, et al. Leucocyte count and bronchial hyperresponsiveness. Journal of Allergy And Clinical Immunology 1988;82(6):100611.

[7] Fabbri LM, Hurd SS, GOLD Scientific Committee. Global strategy for the diagnosis, management and prevention of COPD: 2003 update. Eur Respir J 2003;22(1):1-2.

[8] Gadgil A, Duncan SR. Role of T-lymphocytes and proinflammatory mediators in the pathogenesis of chronic obstructive pulmonary disease. International Journal of Chronic Obstructive Pulmonary Disease 2008;3(4):531-41. 